\title{
Mengenalkan Anak pada Dunia Film
}

\author{
Satya Indra Karsa
}

\author{
ABSTRACT
}

According to research conducted by Yayasan Kesejahteraan Anak Indonesia (Indonesian Children Wealth Foundation-YKAI), children spent their times in front of TV more than 20-25 hours/week, or 3-4 hours/day. Another research stated that children viewing habit reached a relatively high exposure. Based on these facts, this article speaks about the importance to teach children how to appreciate lesson films and other audiovisuals. The process included several steps, such as an introduction to the duty and responsibility of media worker or film maker toward their masterpiece and their audience, reading critics and reference to reduce disappointment if someone meets an underdeveloped or low quality film.

Kata kunci: film, anak, apresiasi

"Pada umumnya, lamanya anak-anak menonton televisi adalah 20-25 jam setiap minggu, atau sekitar tiga sampai empat jam sehari," demikian hasil kajian Yayasan Kesejahteraan Anak Indonesia (YKAI) (Kompas, 24 Agustus 1995).

Dalam hal kebiasaan menonton, dari temuan Biro Pusat Statistik (BPS) menunjukkan, presentase aktivitas menonton televisi tiga kali lebih banyak ketimbang membaca; atau 65,96\%: 22,25\% (BPS, 1993).

Penelitian lain yang dilakukan Arini Hidayati (1996) tentang "Korelasi antara Penggunaan Media Televisi dengan Perkembangan Sosial Anak SD”, terungkap, dari 136 anak yang diteliti, sebagian besar anak $(54,4 \%)$, cenderung menggunakan televisi sebagai media hiburan; sedangkan yang menggunakan media televisi sebagai media informasi ada 62 responden $(45,6 \%)$. Dari jenis acara yang ditonton sebagian besar anak, yaitu 99 responden, memilih acara film, kemudian kuis, berita, dan acara (musik, olah raga, drama) (Hidayati, 1998).

Makna data dan penelitian di atas, menurut penulis, menunjukkan bahwa medium televisi sebagai medium audiovisual telah demikian akrab dengan dunia anak-anak. Medium televisi telah digunakan sebagai saluran untuk menonton film. Bisa jadi, isi film tersebut memang mampu menghibur dan mengenalkan hal-hal baru. Meskipun frekuensi menonton televisi terlalu lama bisa melelahkan mata dan aktivitas lain, membaca, dan bersosialisasi. Dari sinilah kenapa, misalnya, anak-anak lebih menyukai film komik dan kartun dibanding film-film yang menakutkan.

Mengenalkan dunia tontonan kepada anak, tampaknya nyaris luput dari pengamatan, baik dari para pendidik maupun dari orang tua. Maka itu, kegiatan apresiasi terhadap dunia film tersebut 
seyogianya diperkenalkan sejak dini. Tentunya, upaya mengenalkan anak kepada film ini perlu dikelola secara benar. Dengan menonton film-film berkategori 'baik', diharapkan anak memiliki cita rasa tinggi dalam mengapresiasi sebuah karya, khususnya film. Diharapkan seorang anak, kelak, akan memiliki kemampuan untuk menghadapi tantangan zaman. Karya film bersifat netral, tergantung pada apresiasi penontonnya; apakah sebuah film itu memiliki genre keras, porno, romantis, mendidik, bahkan dogmatis, tergantung dari perspektif pengamat itu sendiri.

Begitu beragamnya tayangan film, baik di bioskop maupun di televisi, yang sedikit banyak, langsung tidak langsung, tentu membawa dampak dalam kehidupan anak. Tidak sedikit seorang anak menjadi riang, belajar toleran, bertindak agresif, bahkan menjadi frustrasi, gara-gara melihat tayangan sebuah film, karena, misalnya, sang jagoannya mati atau disakiti. Padahal, kita tahu tokoh-tokoh tersebut hanyalah bersifat fiktif. Semuanya terjadi karena, antara lain, kreativitas tim kreatif, rekayasa special effect, atau sekadar trik kamera. Namun, dalam prosesnya karya kreatif tersebut memerlukan waktu relatif panjang, serta menuntut pula sentuhan artistik, pengetahuan, dan keterampilan yang memadai.

Mengapa film perlu kita apresiasi? Karena film itu sesungguhnya media ekspresi yang potensial dalam memengaruhi emosi penontonnya. Lewat film, penonton bisa di-"teror". Dengan film pula penonton bisa disuguhi sebuah "kenikmatan" artistik. Apalagi jika film dinikmati dengan kadar kesadaran dan tingkat pengetahuan yang memadai. Seperti kata Mangunhardjana, dalam mengapresiasi film sangat tergantung dari latar belakang kebudayaan, pengalaman hidup, pendidikan, pengetahuan dan perasaan film, kepekaan artistik, dan kesadaran sosial mereka (1976:111-112). Jadi, jelas bahwa untuk menikmati sebuah karya film dibutuhkan seperangkat pengetahuan, agar 'dialog' antara pembuat film dengan penonton dapat terjalin.

Karya film merupakan rekontruksi sosial atau gambaran realitas (subjektif). Apa yang divisualisasikan, kerap dianggap realitas.
Tentunya, yang jadi persoalan adalah bagaimana realitas itu ditampilkan dengan bahasa filmis yang cerdas. Seorang penggagas yang memiliki visi dan integritas diharapkan mampu melahirkan karyakarya yang khas, yang sarat makna; bukan karya yang asal jadi atau karya yang sekadar memenuhi tuntutan pasar. Karya film merupakan karya seni, yang tidak terlepas dari kreativitas sutradara. Di tangan sutradaralah karya film lahir. Baik-buruknya sebuah karya film melibatkan banyak aspek. Salah satu unsur yang dimaksud adalah penonton, dalam hal ini anak-anak. Anak dengan segala kepolosannya; dengan segala imajinya bebas berekspresi. Anak bukanlah bejana yang hampa. Bahkan, kita kerap tercengang mengamati kemampuan seorang anak, baik dalam berbicara maupun kemampuan yang lain.

Orang tua kadang keliru ketika menafsirkan perilaku anak saat anak sendirian menonton film serial Baywatch di rumah. Tiba-tiba saja, tanpa alasan yang jelas, orang tua menghardik anaknya kemudian mengalihkan perhatiannya dari tayangan tersebut. Lalu si anak pun menuruti keinginan orang tuanya meski dengan perasaan kesal. Setelah ditanyakan kepada anak tersebut, ternyata si anak bukan melihat tayangan tersebut seperti sudut pandang orang tua. Kita tahu film Baywatch adalah sekelompok muda-mudi yang bertugas sebagai penjaga pantai dengan segala atribut dan permasalahannya. Orang tua menganggap anak tersebut telah menonton sesuatu yang 'belum' waktunya. Si anak melihat film tersebut bertolak belakang dengan yang dipikirkan orang tua. Ternyata, si anak melihat film tersebut karena keindahan alam dan lautnya, sedangkan dia belum pernah ke pantai.

Sebuah film merupakan karya kreatif yang khas, dengan maksud dan ide yang khas pula. Maka, sebetulnya menilai baik-buruknya film, haruslah orang melihatnya secara utuh. Orang tua sebaiknya jangan terlalu khawatir akan dampak buruk dari sebuah tayangan film. Tidaklah bijaksana memang melarang anak menonton tanpa alasan yang jelas. Sepanjang kita-sejak-dini, menanamkan nilai-nilai pemahaman terhadap sebuah karya film, anak-anak akan menjalani hidup 
pada zaman yang lebih 'keras' dengan lebih optimis.

Kurang bijaksana memang jika ada pihak mengaitkan pengaruh media terhadap kebobrokan moral; sikap tak acuh terhadap realitas sosial. Namun, jangan lantas pula menyimpulkan bahwa peran orang tua bisa digantikan oleh media, walaupun dari media anak-anak menemukakan kegembiraan, kesenangan, dan hal-hal baru yang belum pernah mereka lihat. Kekhawatiran para pendidik maupun orang tua terhadap perkembangan anak-anak sejatinya diekspresikan lewat pendidikan ke arah pemahaman media, agar anak lebih siap menghadapi perkembangan zaman.

Jika saja seluruh elemen telah mampu mengapresiasi film dengan segala pendukungnya, maka impian lahirnya masyarakat yang semakin melek media akan terwujud. Kita harus membantu anak untuk memahami segala sesuatu yang berhubungan dengan dirinya. Bukan sebaliknya, memberikan dan memaksakan dunia serta pengetahuan kita kepada anak-anak, tetapi membuka dan menyelamatkan masa depan anakanak kita.

\section{Tahap Perkembangan Anak}

Pada hakikatnya, dalam setiap perkembangan anak terkandung sebuah tujuan, yakni: "menjadi manusia dewasa yang sanggup berdiri sendiri" (Sobur, 2003:140). Tentunya, untuk menjadi manusia dewasa diperlukan berbagai upaya. Setiap perkembangan ditandai oleh beberapa perubahan, baik fisik maupun psikis. Hal ini perlu untuk mempersiapkan seorang anak mampu menghadapi berbagai persoalan hidup yang kompleks. Bisa jadi, ketika ada sebuah perilaku yang merusak, menyimpang, tidak hormat pada yang lebih tua, mengabaikan norma-norma yang berlaku disebabkan ada ruang kosong dalam tahap perkembangan tertentu.

Banyak relitas yang belum waktunya ditangkap indera anak. Anak belum mampu mencerna, memilih, memilah atau menyeleksi, sehingga anak dihadapkan pada situasi yang sulit. Menurut teori perkembangan yang dikutip oleh
Alex Sobur (2003:142) dalam buku Psikologi Umum, menyebutkan bahwa motifutama dari hidup ini ialah: meniadakan dan melepaskan diri dari semua rintangan, rasa tegang, dan disequilibrium batin untuk mencapai kepuasan dan equilibrium batin. Dan keseimbangan akan tercapai jika setiap kebutuhan sudah terpenuhi, sehingga hilanglah semua ketegangan dan gangguan batin.

Mengutip Albert Bandura dengan teorinya Social Learning Theory, Onong Uchjana Effendy, dalam bukunya Ilmu, Teori dan Filsafat Komunikasi, menyatakan bahwa: media massa adalah agen sosialisasi utama di samping keluarga, guru di sekolah, dan sahabat karib (1993: 282).

Dalam Social Learning Theory, langkah pertama untuk belajar adalah perhatian (attentional process) terhadap suatu peristiwa yang merangsang rasa tertarik kita. Langkah kedua, proses retensi (retention process) di mana peristiwa yang menarik perhatian dimasukkan ke dalam benak dalam bentuk lambang secara verbal atau imaginal, sehingga menjadi ingatan (memori). Langkah ketiga adalah proses reproduksi motor (motor reproduction process); hasil ingatan tadi akan meningkat menjadi bentuk perilaku. Kemampuan kognitifdan kemampuan motorik pada langkah ini berperan penting. Reproduksi yang seksama biasanya merupakan produk "trial and error" di mana umpan balik turut memengaruhi. Langkah terakhir, yaitu proses motivasional (motivational process), yang menunjukkan bahwa perilaku akan berwujud apabila terdapat nilai peneguhan. Peneguhan dapat berbentuk ganjaran eksternal, pengamatan yang menunjukkan bahwa bagi orang lain ganjaran disebabkan perilaku yang sama, serta ganjaran internal, misalnya rasa puas diri.

Kegiatan apresiasi terhadap sebuah tayangan adalah suatu kegiatan yang memerlukan latihan terus menerus. Dengan adanya media massa yang menyajikan informasi mengenai hiburan, dalam hal ini televisi dengan program acara film, maka memungkinkan terjadinya proses belajar. Program acara film yang dikemas secara menarik akan merangsang rasa tertarik. Pada dasarnya, ada 
beberapa tahapan yang perlu dilakukan dalam mengapresiasi suatu tayangan.

Tahapan-tahapan kegiatan apresiasi tersebut adalah pengamatan, pemahaman, penilaian, dan penghargaan (Effendy, 1993:102).

Pada tahap pengamatan, penonton berusaha memahami masalah, ide, ataupun gagasan, serta membayangkan dunia rekaan yang ingin diciptakan sutradara bersama tim kreatifnya. Tahap pemahaman, penonton memahami dan menghargai penguasaan pembuat acara terhadap cara-cara penyajian dan teknik pembuatan acara/program. Pada tahap penilaian, penonton juga tertarik pada bagaimana penerapan masalah dramatisasi, pengembangan konflik, klimaks, dan keutuhan skenario secara keseluruhan. Kemudian di tahap penghargaan, penonton memahami pesan moral yang terkandung di dalam tayangan tersebut.

\section{Film sebagai Medium Ekspresi}

Film adalah karya seni yang lahir dari suatu kreativitas dari orang-orang pembuat film, film terbukti memiliki kemampuan untuk menciptakan realitas rekaan sebagai bandingan terhadap realitas.

Bahasa dalam film sebagai alat komunikasi, ekspresi, dan representasi. Hal ini memegang peranan sangat penting. Jarang terjadi pembuat film hanya mengekspresikan dan merepresentasikan dirinya tanpa bermaksud menyampaikan pesanpesan pada penontonnya. Film dibuat untuk pihak lain. Artinya, pembuat film harus mengetahui sasaran penontonnya dan berdialog dengan bahasa mereka.

Film merupakan sarana dialog. Dengan filmnya, pembuat film mengajak penontonnya menerima data, fakta, gagasan, pandangan, pikiran, cita-citanya, dan berbicara tentangnya (Mangunhardjana, 1976:109). Ini berarti, setiap tayangan film mengandung ideologi/pemahaman tertentu yang ingin disampaikan oleh si pembuat film. Jika produk karya film ini sesuai dengan kaidah-kaidah yang berlaku maka tidak menjadi persoalan. Menjadi kontra produktifmanakala film tersebut menampilkan hal-hal yang tidak produktif; film kekerasan, mengeksploitasi wanita, mistik.
Apalagi peredaran/jam tayangnya di saat jam anak sedang belajar. Film kerap menjadi cermin masyarakatnya.

Film melibatkan berbagai keahlian. Banyak tidaknya mereka yang terlibat dengan keahlian masing-masing dalam sebuah produksi film tergantung kebutuhan. Tentu, setiap scene, lokasi yang berbeda memerlukan jumlah dan keahlian yang berbeda pula.

Berikut beberapa keahlian yang dibutuhkan dalam produksi film:

\section{(1) Sutradara/Director}

Sutradara film dan televisi adalah karyawan profesional yang memiliki keahlian untuk memimpin mengarahkan kreativitas/keterampilan teknis sejumlah seniman film dan televisi dengan tanggung jawab penuh atas pengarahannya. Sutradara film adalah pengarah artistik tertinggi dalam sebuah produksi film. Tugas utama sutradara adalah mengepalai semua petugas dalam pembuatan film itu. Bidang kerjanya bukan terletak di dalam salah satu segi, melainkan di dalam keseluruhan pembuatan film itu. Sutradara memimpin pembuatan skenario, permainan para bintang film yang mendukung film yang bersangkutan, pengambilan gambar-gambar oleh juru kamera, perekaman suara oleh juru perekam suara, dan penyusunan gambar-gambar oleh penyusun film, sampai seluruh film itu selesai dicetak dan siap dipertunjukkan di hadapan publik.

Karena itu tidaklah mudah menjadi seorang sutradara yang baik. Untuk itu, seorang sutradara dituntut mengetahui bidang perfilman, mempunyai kepribadian yang matang, bisa berorganisasi, serta memiliki bakat kreatif dan artistik yang memadai.

Jika sebuah screenplay atau skenario diibaratkan sebagai fondasi dan kerangka manusia, maka sutradara adalah seorang yang memberikan otot, daging, kulit, dan segala cairan di dalamnya, berikut sentuhan ruh/jiwa/nyawa, sehingga kerangka manusia tersebut tampak lengkap menjadi manusia yang 'hidup'. Demikian halnya dengan film. Karena film ditujukan untuk kalbu atau emosi manusia, maka sebuah film yang baik, haruslah berkesan hidup atau berjiwa. 
Dalam pandangan Suharyadi (2001:1), tugas seorang sutradara adalah menerjemahkan atau menginterpretasikan sebuah skenario dalam bentuk imaji/gambar hidup dan suara. Secara teknis, hal ini benar. Walaupun ada sebuah catatan kecil yang perlu kita ingat bahwa kadang-kadang kita mengimajikan sebuah adegan atau peristiwa pada sebuah adegan atau peristiwa pada skenario itu hening. Tidak membutuhkan unsur audio atau suara di dalamnya. Maka sah saja jika pada akhirnya seorang sutradara membuat sebuah film tersebut menjadi tanpa suara. Seorang sutradara yang baik adalah seseorang yang mau membuka diri dan berpikir positif pada setiap masukan. Sekali lagi, karena membuat film tidak seperti proses pabrik yang memproduksi benda-benda mati, maka kerja kolaborasi yang 'hidup' akan menjadikan sebuah film mempunyai 'jiwa'. Hal yang kita lakukan terhadap seorang editor, sama pula kita lakukan untuk seorang penata suara dan musik (jika ada). Editing dan akting adalah tanggung jawab sutradara.

\section{(2) Juru Kamera}

Juru kamera (Cameraman) adalah karyawan profesional yang dalam produksi film, baik film cerita maupun noncerita, melaksanakan rekaman gambar dan bertanggung jawab di bidang cinephotography. Tugas seorang juru kamera adalah mengambil gambar-gambar untuk disusun menjadi film. Dialah orang yang bertanggung jawab sepenuhnya atas segala segi fotografis dari film yang dibuat.

Untuk membuat gambar-gambar film itu juru kamera dibantu oleh director of photography, yang ahli dalam hal penggunaan alat-alat foto, camera operator; yang menjalankan kamera, focus fuller atau camera assistant; yang memperhatikan tepat tidaknya memasang dan arah lensa sewaktu terjadi pengambilan gambar-gambar, dan masih dibantu oleh beberapa tenaga teknis lagi.

Begitu skenario disepakati, kini giliran penata fotografi (director of photography/DOP) yang bekerja. Di Indonesia, selama bertahun-tahun jabatan fotografi sering disalahartikan sebagai operator kamera (cameraman). Pendeknya, penata fotografi merancang apa yang harus dilakukan oleh para operator kamera (Effendy, 2002:67). 'Filter', 'emulsion', proses, dan cara pencahayaan adalah seratus persen tanggung jawab juru kamera. Tetapi, komposisi gerakan, kadang-kadang lensa, dan efek pencahayaan adalah hal-hal yang memerlukan perhatian dari juru kamera dan sutradara di mana ada hubungan dengan pola editorial dan keadaan jiwa dari scene-nya .

Sutradara dan juru kamera tidak boleh menyalahgunakan hak istimewa mereka, dan keduanya tidak boleh bersikap seperti diktator. Mereka harus memecahkan persoalan mereka secara bersama, saling menghargai dan juga menghargai kemauan masing-masing untuk mencapai hasil yang baik. Produser atau executive studio, bila memberikan tugas, harus mempertimbangkan kepribadian sutradaranya dan juru kameranya; tetapi mereka juga memperhitungkan pengeluarannya apakah hal itu layak.

\section{Mengapresiasi Film}

Kadar persepsi, daya tangkap seseorang terhadap unsur-unsur film adalah tidak sama. Maka perlu kita telaah kebenarannya. Salah satu yang harus diwaspadai adalah promosi atau poster. Sebab, yang penting dari promosi atau poster tersebut adalah produser atau sutradara. Dengan memahami itu, kita tidak akan kejebak. Produser atau sutradara yang memiliki visi/karakter cenderung tidak akan menurunkan reputasinya dengan membuat film-film 'tidak bermutu', pasaran. Garin Nugroho, Eros jarot, adalah segelintir orang film yang memiliki reputasi atas hasil karyanya.

Salah satu tips dalam mengapresiasi film, adalah kita harus bersikap terbuka terhadap segala jenis film. Dengan demikain, kita bisa terus menerus merespons film-film secara emosional, intuitif, maupun subjektif(Sumarno: 1996:106).

Sebelum menonton sebuah film, sebaiknya kita melihat terlebih dahulu referensi, ulasan, $r e$ view, kritik, apresiasi film dalam media massa, agar kita tidak kecewa.

Menikmati film merupakan suatu seni, bukan sesuatu yang ilmiah. Pendekatan apresiatif mestinya dapat membantu atau melatih tanggapan 
emosional dan intuitif kita, dan bukan malah merusak atau menghancurkan.

Jika dilatih dengan baik, khususnya untuk anak-anak usia dini pendekatan apresiatif akan memperkaya, menguak kesadaran baru, serta menolong kita menjadi makin mahir dalam seni menikmati film.

\section{Daftar Pustaka}

Darwanto. 1991. Produksi Siaran Televisi. Yogyakarta: MMTC.

Effendy, Uchjana, Onong.1993a. Televisi Siaran Teori \& Praktek. Bandung: CV. Mandar Maju.

1993 . Ilmu, Teori, dan Filsafat Komunikasi, 1993, Bandung: Citra Aditya Bakti.

Effendy, Heru. 2002. Mari Membuat Film. Yogyakarta: Panduan dan Yayasan Konfiden.

Hidayati, Arini. 1998. Televisi dan Perkembangan Sosial Anak. Yogyakarta: Pustaka Pelajar.

Hofmann, Ruendi. 1999. Dasar-Dasar Apresiasi Program Televisi. Jakarta: Grasindo.

Irawanto, Budi. 1999. Film, Ideologi, dan Militer. Yogyakarta: Media Pressindo.

Lubis, Mochtar. 1953. Teknik Mengarang Skenario. Jakarta: Balai Pustaka.

Mufid, Muhamad. 2005. Komunikasi dan Regulasi Penyiaran. Jakarta: UIN Press.

Mulyana, Deddy dan Idi Subandi Ibrahim (ed.) 1997. Bercinta dengan Televisi. Bandung: Remaja Rosda Karya.
Nashir, MJA. 2001. Membela Anak dengan Teater. Yogyakarta: Kepel Press.

Said, Salim. 1991. Pantulan Layar Putih. Jakarta: Sinar Harapan.

Saptaria, El., Rikrik. 2006. Acting Handbook, Panduan Praktis Akting untuk Film \& Terater. Bandung: Rekayasa Sains.

Set, Sony dan Sidharta Sita. 2004. Menjadi Penulis Skenario Profesional. Jakarta: PT. Grasindo.

Sobur, Alex. 2003. Psikologi Umum. Bandung: Pustaka Setia.

Sudjas, Winarno, dkk. 2002. Estetika Film. Jakarta: Kerjasama IKJ dengan Asisten Deputi Urusan Fasilitas dan Pengembangan Perfilman Kementerian Kebudayaan dan Pariwisata.

2002. Peta Perfilman Indonesia. Jakarta: Kerjasama IKJ dengan Asisten Deputi Urusan Fasilitas dan Pengembangan Perfilman Kementerian Kebudayaan dan Pariwisata.

Sumarno, Marselli. 1996. Dasar-Dasar Apresiasi Film. Jakarta: Grasindo. 1997. D.A. Peransi \& Film. Jakarta: Direktur Jendral Kebudayaan Departemen Pendidikan dan Kebudayaan.

Wibowo, Fred. 1997. Dasar-Dasar Produksi Program Televisi. Jakarta: Grasindo.

Wisjnu, Lingga. 1975. Tehnik Mengarang Naskah. Jakarta: Balai Pustaka.

Wurtzel, Alan, dan Stephen R. Acker. 1989. Television Production, Third Edition. New York: McGraw-Hill Book Company. 